\title{
EL NIÑO: A DESTRUCTIVE OCEANOGRAPHIC PHENOMENON
}

Vidya Narine, Natural Science

Division, College of The Bahamas

The Peru Current System, one of the most productive maxine system known, is characterized by abundant upwelling, enrichnent of surface waters with nutrients, diverse plankton communities, and vast cormercial resources. Nevertheless, from time to time the dynamic patterns of the Peruvian Current are drastically altered by changes in the atmospheric and hydrospheric conditions; such alterations are known by the name "El Niño".

Recent meteorological and oceanographic conditions existing along the PeruEcuadorian coastline indicate the presence of El Niño. This phenomenon portends massive destruction of property and loss of important marine biological resources which form the economic base of the coastal peoples.

\section{INTRODUCTION}

El Niño is the periodic appearance of excessively warm water flowing southward off the coast of Peru during the end of the year. It coincides with the Southern Hemispheric summer, with the season of weaker winds, and the time of reduced upwelling (Wyrtki, 1975). As such, it should be a normal annual event, but in the following years there have been conspicuous upheavels: in 1891 (Schott, 1931); in 1925 (Murphy, 1y26); in 1941 (Lobell, 1942); in 1953 (Posner, 1954); in 1957-58 (Bjerkness, 1961, 1966; Wooster, 1960); in 1965-66 (Guillen, 1971); and more recently in 1972-1973 (Miller and Laurs, 1975; Wooster and Guillen, 1974).

During the above-mentioned years, the E1 Niño conditions were characterized by a large scale weakening of the Southern Hemisphere trade wind system, cessation of upwelling along the Peruvian and Ecuadorian coasts, and the sudden appearance of anomalously warm low-salinity water far beyond its usual summer limits. The attributable consequences of these events included decrease in productivity, redistribution of tropical and subtropical fauna, reductions in abundance and availability of fish stocks (primarily Anchoveta, (Engraulis ringens) and the mass mortality of guanay (Phalacrocorax bougainvilli).

The objectives of this paper are:

1) to describe the general characteristics of the El Niño phenomena

2) to examine the surface hydrographic and meteorologic anomalies which contribute to the development of the event; and

3) to summarize the major concepts of hypotheses on the origin of EI Niño.

GENERAL INFORMATION ON EL NIÑO

To the fishermen and coastal inhabitants of Central and South America, in particular Ecuador and Peru, E1 Niño has meant unusually warm coastal waters, red tide, poor fishing, and frequent torrential rains, al1 culminating at the end of the year. Although El Niño is a colloquial term with religious connotations (refers to the Christ Child, a name chosen because of the coincidence of this phenomenon near the traditional date of Christmas), its original application apparently is not known. Other names given to this abnormal oceanographic-meteorological phenomenon axe "El Pintor" or "Callao Painter" which refers to the blackening of the hulls of boats and of houses by hydrogen sulphide released from decomposition of marine organisms (Wooster, 1960); "Aguaje" which probably means flooding from rains and the occurrence of red tide, which usually occur simultaneously along Peru and Ecuador from December to February during El Niño years; and the "corriente del Niño" or "Holy Child Current" identified by fishermen as a southward moving current occurring near the end of the year, in contrast to the Peru Current which normally moves northwards (James, 1953; Hawken, 1973).

In years of a very weak El Niño or nonEl Niño years, the cool Peru Current predominates with a cold northward drift under extensive low stratis cloud cover, creating a desert-like climate which extends from 
"Sea-surface temperature conditions during El Niño years apparently follow a fourfold pattern:

1) there is rapid waming from subnormal to above normal temperatures followed by

2) a slight shift to near normal temperatures then

3) a second period of warming, to wellabove-normal temperatures, which persist for several months, and finally

4) a rapid return to normal or cooler than normal temperatures.

Applying data obtained during the 1972-73 E1 Niño (Miller and Laurs, 1975; Wooster and Guillen, 1974), these four phases of the EI Niño condition can be easily seen. Colder than nomal temperatures persisted generally over much of the eastern tropical Pacific from late 1969 to Jamuary 1972. However, the situation changed dramatically in February 1972 (Figures $2 a$ and $2 b$ ), when a warm regime (with anomalies as much as $6^{\circ} \mathrm{F} / 3.3^{\circ} \mathrm{C}$ ) was established south to $10^{\circ} \mathrm{S}$. This warming trend which continued into March, 1972 represented the initial warming period. Although higher than normal temperatures continued during Apri1, 1972, there was no significant intensification of the warming trend and in fact, temperatures of inshore waters returned to near normal, and in some areas as much as $4^{\circ} \mathrm{F} / 2.2^{\circ} \mathrm{C}$ above nomal. This lowering of sea-surface temperatures during April and May, 1972 indicated the return to normal phase.

The second warming period began in June, 1972 and extended through August, 1972. Between $80^{\circ} \mathrm{W}$ and $90^{\circ} \mathrm{W}$ temperatures were as much as $6^{\circ} \mathrm{F} / 3.3^{\circ} \mathrm{C}$ above normal (Figure $3 a$ and $3 b$ ). The E1 Niño conditions continued during the southern spring months and through January, 1973, with anomalously warm waters occurring generally along the coast of Peru and Ecuador. It was not until February, 1973 that the extent and magnitude of the positive temperature anomaly decreased from what it had been since June, 1972. By Apri1, 1973, the El Niño ended when normal or below-normal ocean temperature conditions returned along most of the coastal areas.

2. Surface Salinity Distribution along the Peruvian Coast.

Average surface salinity distribution data are not as comprehensive as those of seasurface temperature. The principal salinity characteristics of this area were observed on the EASTROPAC cruises of FebruaryMarch, 1967 (Love, 1972). The charts show average surface salinity values for coastal regions of $34.9-35.0 \%$ in winter and $35.0-35.3 \%$ in summer.
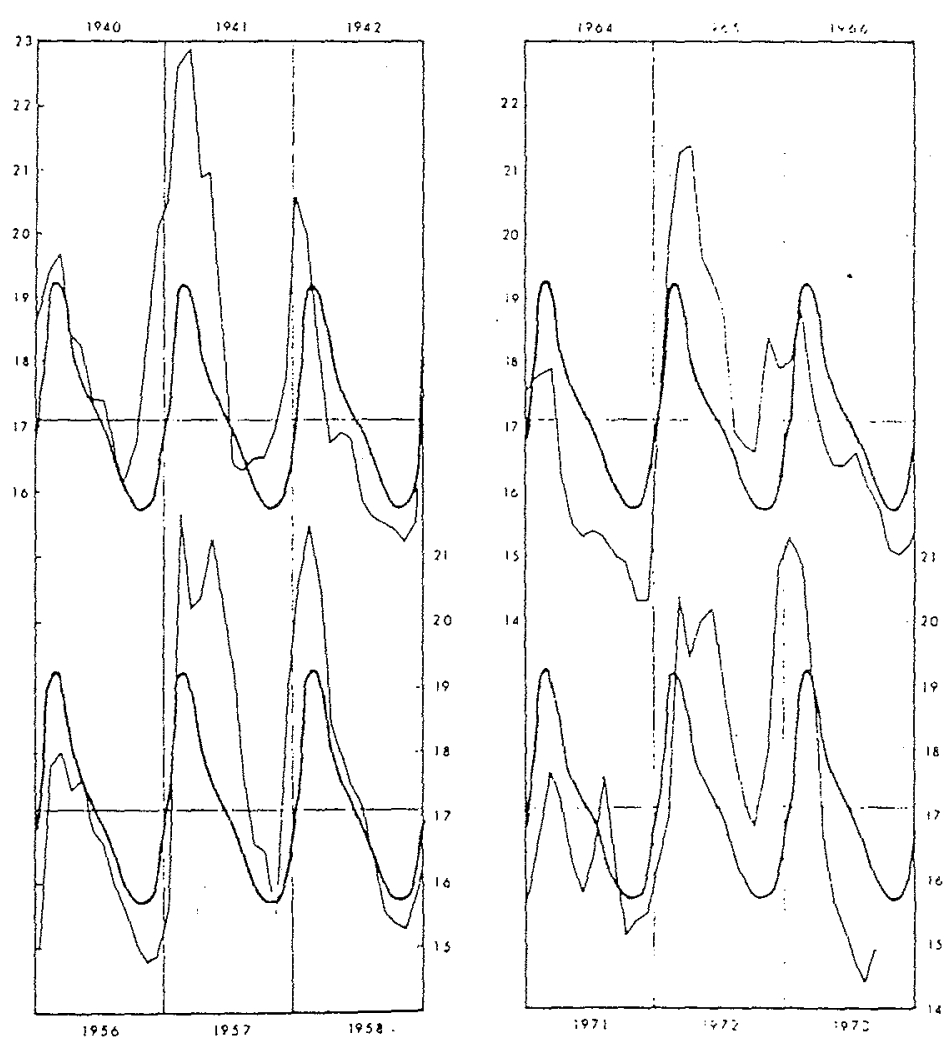

tiv. Fig. 1. Sea surface temperature $(0 \mathrm{C})$ at Puerto Chicama ( 705$)$ during thii the last four El Nino events. The thin line gives observed monthly mean temperature, the heavy line the mean annual variation $(1925-1973)$ 
Chile to soithern Ecuador. In contrast, E1 Niño years are associated with a major shift in the atmospheric pressure system, extending from South America to at least the central South Pacific. Beginning in the southern winter of one year, extensive heat exchange from the warm coastal water induces tropical-like rains and frequent flooding along coastal plalns. This condition ceases during the southern spring; but when coastal atmcspheric pressure systems persist with weak southeast tradewinds, a second period of warming takes place during the ensuing sumer.

In the last 50 years, sea-surface temperature curves (SST) have demonstrated that El Niño is an event which lasts for about 16 months, namely two sumers and one winter. The first peak in temperature is not always the highest, but apparently the longest. Figure 1 shows the SST during the last four major E1 NAño events. Stevenson et al. (1970) have noted that peaks in $\mathrm{E} 1 \mathrm{~N}$ ño conditions occur at intervals of $\mathrm{s} i \mathrm{x}$ and 16.5 years at coastal stations in Peru and Ecuador. Wyrtki (1975) has summarized the most striking features of these patterns as:

1) The extremely sudden rise of temperature at the onset of El Niño.

2) The repitition of the event in two successive years。

3) The return to almost normal conditionsin late winter between two temperature maxima.

Wocster and Guillen (1974) have listed the following consequences:

1) Coastal upwelling weakens or ceases.

2) With weakening of the coastal divergence, offshore waters of high temperature and salinity approach the coast.

3) Equatorial waters of high temperature and low salinity extend in a thin layer southward slong the coast, far beyond their usual sumer position.

THE EL NIÑNO CONDTTIONS: CAUSES AND EFFECTS

\section{A. HYDOGRAPHIC FEATURES}

1. Surface Temperatures along the Peruvian Coast.
Monthly average sea-surface temperatures for the period 1928-1969 for the region of the Peruvian coast ( 30 to $18^{\circ} \mathrm{S}$ ) have been computed by Zuta and Urquizo (1972). Charts based on these averages show the seasonal variations in strength and position of the warm equitorial front as it intersects the coast and the annual development of the warm tongue offshore. This tongue is most strongly developed in January, but is evident from November through April. Bjerkness (196I) hypothesized that it is fed by a south equatorial counter current, possibly augmented by the eastward flow near the equator from the Cromwell current and by transequatorial flows of tropical water at times when the southeast trades are weak or absent.
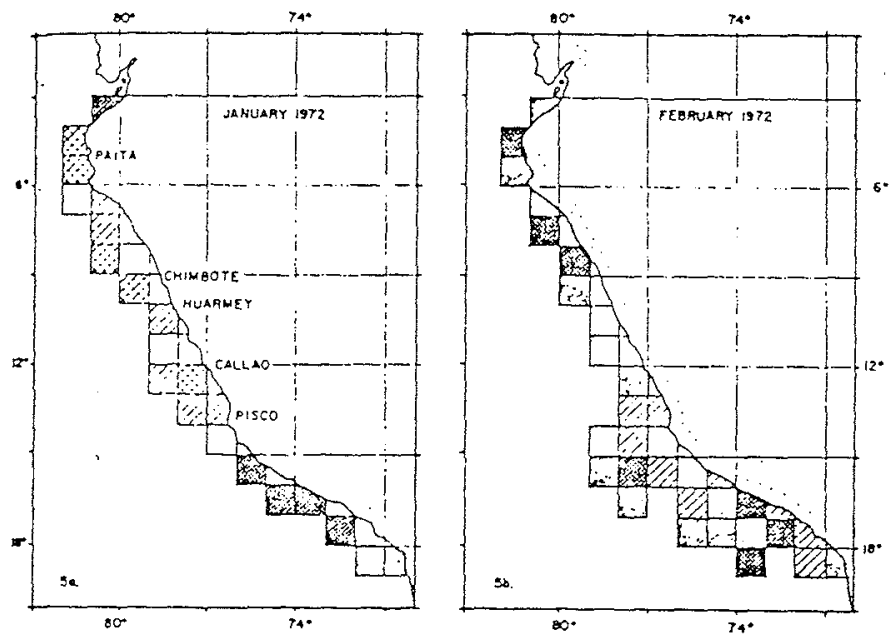

rase 2a. Deviation of sea surface temperature $\left({ }^{\circ} \mathrm{C}\right)$ fromiong term mean, coast of Peru, for January 1972.

2b. Same, for February 1972 . From Instituto de! Mar. Positive anomalies $1.0-1.9^{\circ} \mathrm{C}$ ligbe solid shade, greater than $1.9^{\circ} \mathrm{C}$ dark solid shade. Negative anomaltes $1.0-1.9^{\circ} \mathrm{C}$ single lines, greater than $1.9^{\circ} \mathrm{C}$ crossed lines.
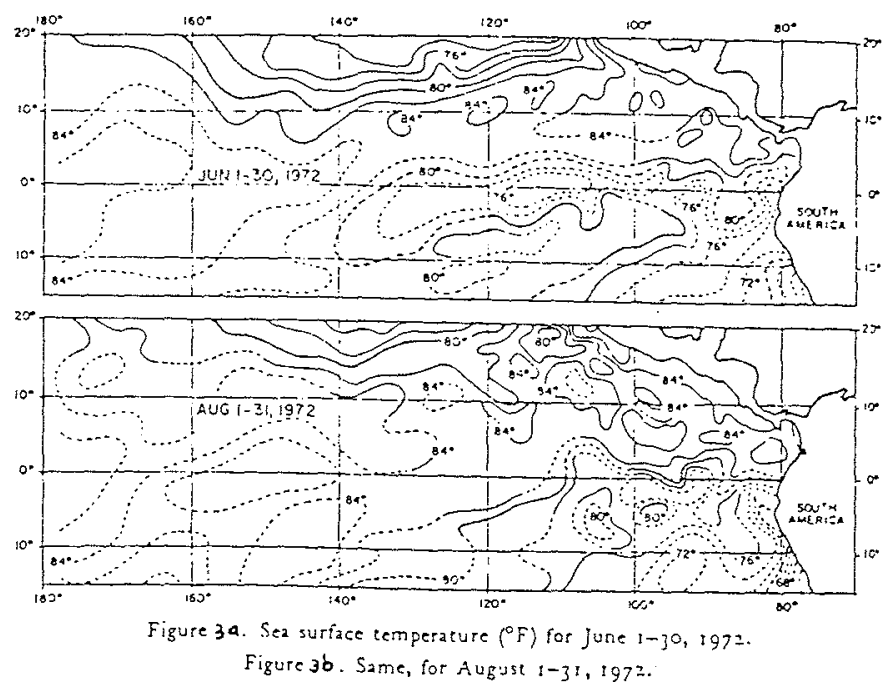
Surface salinity observations taken on several crufses by the Instituto del Mar demonstrated some features of the 1972-73 EI Niño occurence. In February 1972, abnormal conditions were already established in the northern regions, with surface waters of low salinity (less than $34.5 \%$ oo). The invasion of this warm, low salfity tongue continued southward along the coast, reaching $11^{\circ} \mathrm{S}$ by the end of April (Figure 4a). By June 1972, the troplcal waters receded and normal to close-to-normal conditions were restored along the coast.

However, in December 1972 the troplcal waters reappeared and pushed even further south than previousiy (FIgure 4b). Unfortunately, no observations were made beyond $12^{\circ} \mathrm{S}$, hence the extent of the low salinity tropical water wedge was not documented. During February and March 1973, observations showed that the low salinfty water was no longer present, but it was not until April 1973 that coastal conditions facilitated the re-establishment of upwelling.

Observations of surfacr salintty are useful for tracing the orlgins of the warm surface waters, which are characteristic of El Niño pertods. Wooster (1960) and Guillen (1974) suggested three source reglons: nearshore, north of the equator; offshore, west of Central Peru; and near the Galapagos Islands. Apparently, surface waters of low salinity are always present along the Ecuadorian coast and reach Peru in the southern sumer. This coastal flow of low salinity water fs normally separated by the higher sallnity water of the Peru Current. During EI Niño events, this wedge of higher salinfty water may be weakly developed or completely absent. The southerly flow of troplcal waters (previously discussed) coalesce with the coastal low salinity water, resulting in the salinity anomalies characteristic of the NAño invasions.

\section{B. ATMOSPHERIC INFLUENCE}

Bjerkness (196I, 1966), Quinn (1974) and Wyrtki (1975) have demonstrated the development of E1 Niño conditions along the South American coast in relationship to atmospheric pressure systems. During periods of El Niño, there are periodic relaxation or decrease in velocity of the southeast tradewinds off the continental land mass. This deacceleration results in the decrease in surface wind stress needed to maintain vertical mixing (upwelling) in the Peru Current system.

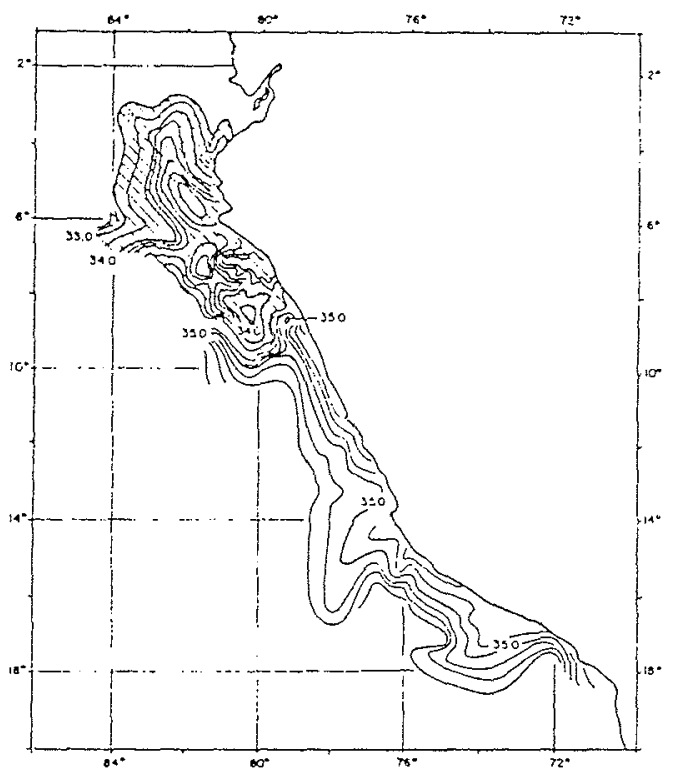

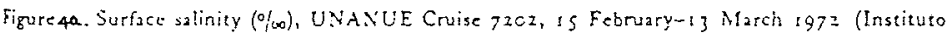
del Mar). Salinity leys than $37.5 \%$ shaded.

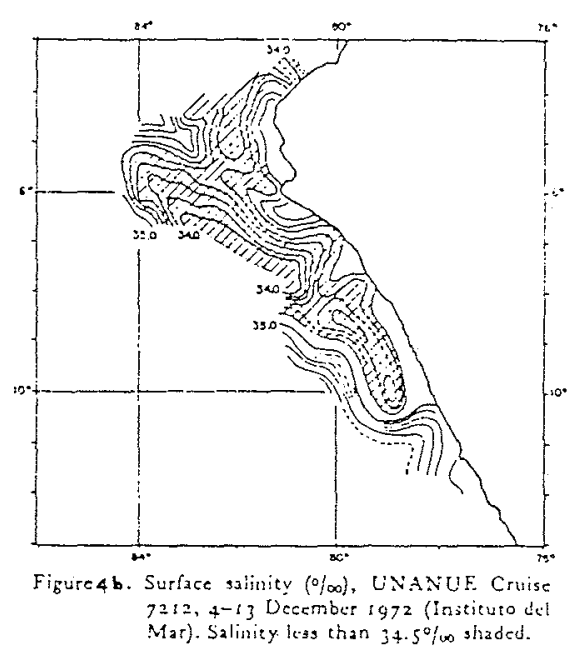


Wind stress data have demonstrated that EI Niño years are preceded by abnormally strong southeast trades, as shown in 1955-1965 and in 1970-1971 in Figure 5 . Quinn (1974) has used the Southern Oscillation Index (the atmospheric pressure difference between Easter Islands and Darwin, Australia) as a predictive index for El Niño. According to his calculations, E1 Niño will occur after the pressure difference has been high (greater than $3 \mathrm{mb}$ ) for an appreciable period of time (Figure 6). A closer examination of the peaks in the oscillation indices reveal that they also coincide with periods of decreased southeast trade winds.

During the period of strong southeast tradewinds, the circulation in the subtropical gyre of the south Pacific is intensified; especially in the South Equatorial Current (Wyrtki, 1975). This intensification has been shown to exist from time series observations of differences in sea-level (Wyrtki, 1974). These strong tradewinds also lead to a build up of water in the western Pacific Ocean, in particular, the region from Samao to the Solomon Islands. As soon as the stress of the southeast trades are relaxed, the strong east-west slope of sea level can no longer be maintained, and the water accumulated in the western Pacific must flow back to the east. Such movement of water eastward could occur by internal equatorial Kelvin waves, as postulated by Lighthill (1969) and Godfrey (1975). The relaxation in wind stress will also result in a slow down of the South Equatorial Current, which will allow for the intensification of the equatorial counter-current and for the equatorial under-current to increase in strength.

The water flowing into the area off Peru causes a depression in the thermocline; hence the disappearance of the cold surface waters along the coast. Since the South Equatorial Current is slowed down, advective processes are reduced and thus residence time of water in the area is increased. Exposure to strong solar radiation accounts for the increase in temperature of the surface waters during EI Niño periods. Theoretical studies have confirmed these observations. White and Mcreary (1974), using a "spindown" model of a subtropical gyre system, demonstrated that a slowdown of the circulation from a very intense state to a more relaxed state can bring about the characteristic features observed during El Niño periods. Hurlburt et al. (1976), applying numerical simulation techniques based on a "spinup" mode1, also concluded that relaxation of the wind stress results in an eastward acceleration along the equator and initiates the formation of internal Kelvin waves.

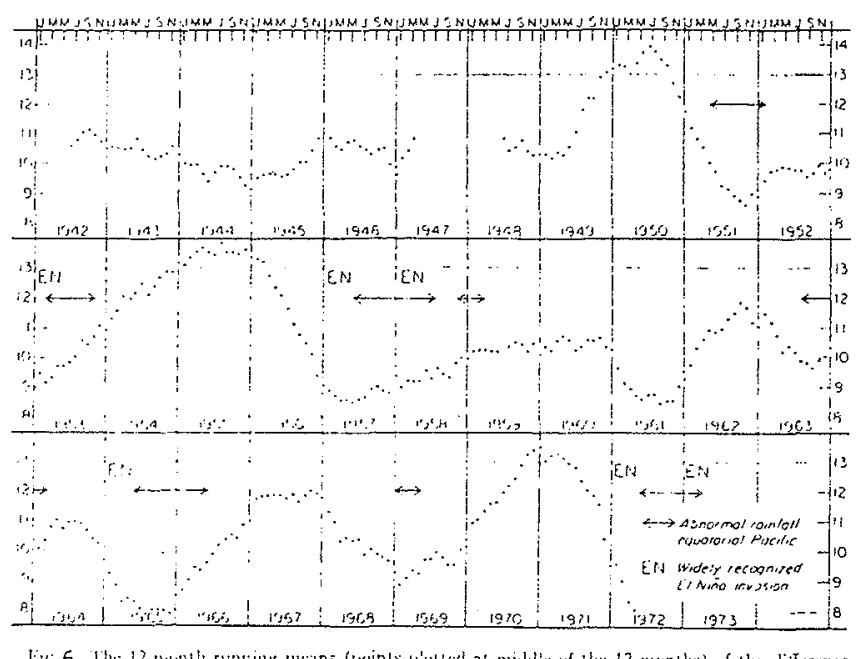

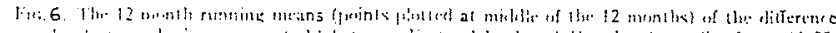

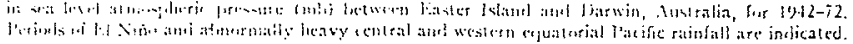




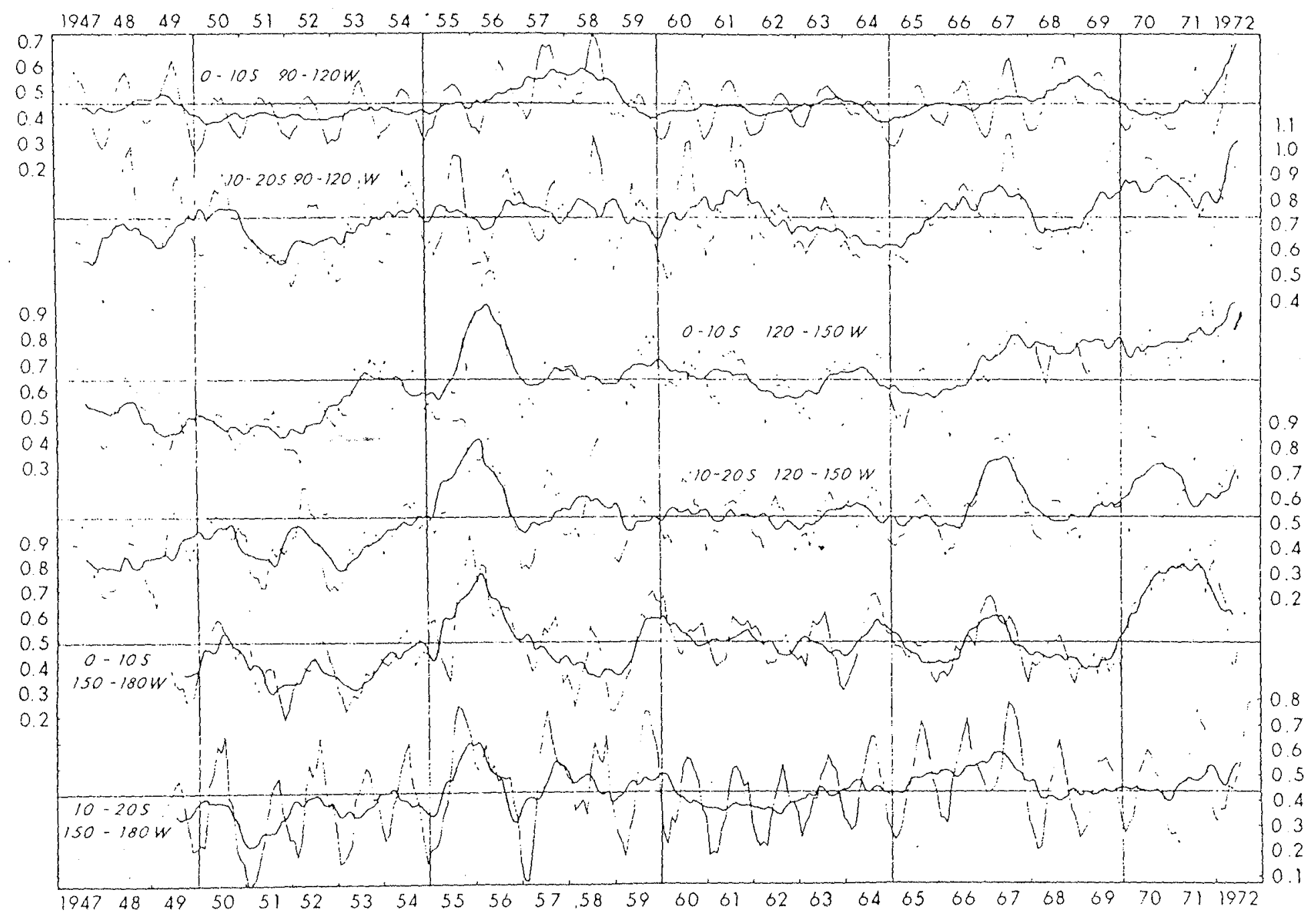

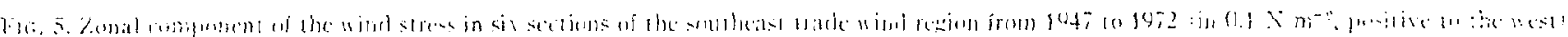

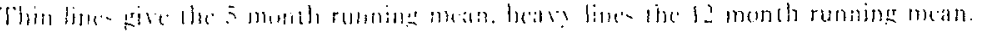


HYPOTHESES ON THE ORIGIN OE EL NIÑO

Wyrtki et al. (1976) have summarized the major results of the investigations and their value in predicting the onset of El Niños. Although EI Niño events are much more complex than those stated in the above mentioned paper, there appears to be three generally accepted hypotheses. Currie (1953) and Bjerkness (1966) are of the opinion that strong northerly winds sweep southward in the Gulf of Panama and east of the Galapagos Islands, displacing the inter-tropical convergence zone into the southern hemisphere. This displacement of the pressure cell causes a southward advection of warm low salinity equatorial water to flow down the coast of South America. Schott (1931) and James (1953) hypothesized an eastward advection transport of warm water from the Galapagos Islands region. Stevenson et al. (1970) have suggested that this eastward flow was associated with the South Equatorial countercurrent, and that this current may have transported warm water to the coast during E1 Niño years. According to Sears (1954) and wooster (1960), when the southeast tradewinds decrease and vertical mixing (upwelling) becomes minimal in the Peru Current, in situ heating occurs in the surface waters along the coast. Great amounts of moisture are carried up onto the atmosphere during these heating periods and the resulting heavy precipitation which accompany EI Niño may also, in part, account for the lowered surface salinity anomalies along the PeruEcuadorian coast.

Wooster (1960) proposed the hypothesis that "during $E 1$ Niño years, there is a general weakening of the atmospheric circulation in the marine layer, and reduction in the wind-stress component parallel to the coast is responsible for a weakening or cessation of upwelling". In concluding, he stated that the EI Niño phenomenon does not apply to the Peruvian coast, but also to the west coast areas of California, southwest Africa, western Australia and Vietnam.

Bjerkness (1966), in considering the atmospheric perturbations of the 1957-58 El Niño, concluded that, "El Niño is a summer phenomenon of the southern hemisphere and the high sea temperature measured in that season is a by-product of the annual insolation maximum, especially in the trade-wind belt where there is little cloud...weakness of the trad winds has more sudden and spectacular ocean effects in terms of temperature induced by cessation of upweliing... whenever an area of upwelling water happens to be covered up by the invasion of warm surface water, the atmosphere is exposed is exposed to a new heat source creating vertical convection exchange and rainfall".

Berlage (1966) and Quinn (1974) suggest that the slowing down of the Peru current is related to the "Southern Oscillation Index". In this situation, the general atmospheric and hydrospheric circulations throughout the south Pacific Ocean are decreased. As a result, the Peru current becomes weaker or absent, and relatively warm water along the Peru Coast forms part of the South Equatorial Current system.

\section{CONCLUSION}

El Niño is a complex oceanic phenomenon whose occurrence results in deleterious environmental and economic effects. The appearance of warm low salinity water off the northern sector of the South American coast, heavy rainfall, the drop in fish catches, and the mass mortality of gauno birds are only the end products of along series of hydrospheric-atmospheric

interactions. Past $E 1$ Niños have showed varying intensities and like many other events involving ocean-atmosphere systems, they cannot be fully explained by any one single variable. In fact, no two El Niño events are the same; the anomalous temperature in the second year was missing in the $1965 \mathrm{El} \mathrm{Niño} \mathrm{and} \mathrm{in} \mathrm{other} \mathrm{minor}$ El Niños in 1951 and 1953 neither was preceded by strong southeast tradewinds.

Thus far, a significant body of information has been gathered, but much more research will be required to fully comprehend the extent of the ocean-atmosphere exchange processes preceding and during an EI Niño event. At the present time, observational data in the area indicate that 1982 was a warmer than a normal year, with characteristics not unlike those of a year leading up to an E1 Niño. The JOTNT II Oceanographic activities (CUEA), currently being conducted along the Peruvian coast, may provide valuable information should 1983 prove to be another "Year of the El Niño". 


\section{POSTSCRIPT}

This paper was written in January, 1983 based on the Iimfted world meteorologlcal data locally available. However, it was conflrmed in April, 1983 that the EI Nino event did occur and was perhaps one of the strongest on recordo This occurrence marks the first time it has manlfested itself fully in the past ten (10) years。EI Niño has also been Implicated by United States meteorologists for the unusual weather patterns and regional weather-related disasters experienced thus far on the North American continent。 
BERIAGE, H. P., 1966。 The southern osclilation and world weather。 Mededeel Verbandel。, Ned., Ned。 Meteor. Inst。 88:152.

BJERKNESS, J., 1961. El Niño study based on analysis of ocean surface temperatures, 1935-57 (in English and Spanish). Inter-Am. Tuna Com. Bull。 5(3):217-303。

BJERKNESS, Jo, 1966. Survey of EI Niño 1957-58 in its relation to tropical Pacific meteorology (in English and Spanish)。Inter-Am. Tuna Comm。Bull. 12(2):25-86.

CURRIE, $R_{0}$, 1953。 The Callao Painter, Weather $\underline{8}(10): 308-311$.

GODFREY, J., 1975. On Ocean spin-down I: A Ifnear experiment. J. Phys。 Oceanogr. $5: 399-409$.

GUILLEN, O。, 1971。 The "E1 Ndño" phenomenon in 1965 and its relation with the productivity in coastal Peruvian waters. In: Fertility of the Sea. J. D. Costlow (Ed.), Gordon and Breach (Publs。) Vol.1:187-196.

BAWKEN, C.G., 1973. The Holy Child Current, Peruvian waters, The Mar。 Observ. $63(239): 11$.

HURLBURT, H. E., J. C. Rindle, and J。J. O'Brien. 1976. A numerical simulation of the onset of E1 N1ño.J. Phys. Oceangr. $6(5): 621-631$.

JAMES, P. A., 1953. Aguaje, the Callao Palnter. Weather $8(7): 208-209$ 。

LICHTEIIL, M. J., 1969。 Dynatic response of the Indian Ocean to onset of the southeast monsoon。 Ph11. Trans. R. Soc. London 265:465-473。

LOBELL, M. J., 1942. Some observations on the Peruvian Coastal Current. Trans. Amer。 Geophys. Un. 1942 2: $332-336$ 。

LOVE, C. M., (Ed.) 1972. EASTROPAC Atlas, Vol。 I Physical oceanographic and meteorological data from principal participating ships, first survey cruise, February-March, 1967. National Marine Fisheries Service, U。S。Department of Comerce, Circ。330.

MILLER, F. R., and R. M. Laurs. 1975 The EI Niño of 1972-73 in the Eastern Tropical Pacific Ocean (in English and Spantsh). Inter-Am。Tura Com. Bull。16(5):403-448。

MURPHY, R. C., 1926. Oceanfc and climatic phenomena along the west coast of South America during 1925. Gecgr。Rev。16(1):26-54。

POSNER, G. S., 1957. The Peru Current。 Bull. Bingham Oceanogr. Coll。 16(2):106-155.

QUINN, W.H., 1974. Monitoring and predicting El Niño invasions. J. Appl. Meteor. 13:825-830。

SEARS, M., 1954. Notes on the Peruvian coastal current. 1. An Introduction to the ecology of Pisco Bay。 Deep-Ser Res.1:141-169. 
STEVFNSON, M.R., O。GUILLEN G., and Santero de Ycaza, 1970 Marine Atlas of the Pacific coastal waters of South America. Univ. Callfo Press 23 pp, plus charts.

WEITE, W.B., and J.P. McCreary. 1974. Eastern intensification of ocean spindown: Application to EI Niño. Jo Phys. Oceanogr. 4:195-303.

WOOSTER, W.S. 3960. El Niño.Calif. Coop. Cceanic. Fish Invest. Rep. Z:43-45.

WOOSTER, W.S., and O. GUILLEN。1974. Characteristics of E1 Niño in 1972. J。Mar. Res. $32(3): 387-404$.

WYRTKI, K., 1974. Equatorial currents in the Pacific 1950 to 1970 and their relations to the Trade Winds. J. Phys. Oceanogr。 $4: 372-380$.

WYRTKI, Ko, 1975 El Niño -- the dynamic response of the equatorial Facific Ocean to atmospheric forcing. J. Phys. Oceangr。 5:572-584。

WYRTKI, K., E.S. STROUP, W. PATZERT, R. WILLIAMS, and W. QUTNN., 1976. Predicting and observing E1 Niño. Science 191:343-346.

ZUTA, S. and $W$. UROQUIZO., 1972. Temperature promedia de la superficie del mer frente a la costa Peruana, pertdio 1928-1969. Bol。Inst. Mar. Feru. $\underline{2}(8): 462-519$ 。 